\title{
Concentrate containing calcium salts of fatty acids rich in polyunsaturated fatty acids can change rumen fermentation in grazing goats
}

\section{Concentrado contendo sais de cálcio ricos em ácidos graxos poli- insaturados altera a fermentação ruminal de cabras na pastagem}

\author{
Ludmila Couto Gomes ${ }^{1 *}$; Claudete Regina Alcalde ${ }^{2}$; Julio Cesar Damasceno; \\ Luiz Paulo Rigolon ${ }^{2}$; Ana Paula Silva Possamai ${ }^{1}$; Bruna Hygino ${ }^{1}$
}

\begin{abstract}
Feeding goats with calcium salts of fatty acids (CSFA) can supply ruminants with lipids, with minimal effects on ruminal fermentation and fiber digestibility. However, there is a shortage of information on the effect of CSFA on characteristics of rumen fermentation in grassland goats. Thus, the present study aimed to assess the addition of CSFA to concentrate on the parameters of rumen fermentation of grazing goats. Five rumen cannulated goats were distributed in a Latin square $5 \times 5$ design (treatments: $0 \%, 1.5 \%$, $3.0 \%, 4.5 \%$ and $6.0 \%$ CSFA. The $\mathrm{pH}$, ammonia $\mathrm{N}$ and volatile fatty acids (VFA) content were analyzed in the ruminal fluid at $0,2,4,6$ and 8 hours after concentrate supplementation. The $\mathrm{pH}$ and ammonia $\mathrm{N}$ concentration showed a linear effect with the addition of CSFA. There was no effect observed for the VFA molar concentration after grazing goats were fed with the experimental diet. In conclusion, further research is needed to investigate the addition of CSFA to goat diets because there is evidence that CSFA increases ruminal $\mathrm{pH}$ and decreases excess ruminal ammonia without changing the VFA concentration in the rumen fluid.
\end{abstract}

Key words: Ammoniac nitrogen. Digestibility. Fat supplementation. N-alkanes. Volatile fatty acids.

\section{Resumo}

\begin{abstract}
Alimentar cabras com sais de cálcio de ácidos graxos (SCAG) pode fornecer aos ruminantes lipídios, com efeitos mínimos na fermentação ruminal e digestibilidade das fibras. No entanto, há escassez de informações sobre o efeito da SCAG sobre as características da fermentação do rúmen em cabras de pastagem. Assim, o presente estudo teve como objetivo avaliar a adição de SCAG no concentrado de cabras na passagem sob nos parâmetros de fermentação ruminal. Cinco cabras canuladas do rúmen foram distribuídas em um quadrado latino $5 \times 5$ (tratamentos: $0 \%, 1,5 \%, 3,0 \%, 4,5 \%$ ou $6,0 \%$ de SCAG). O pH, $\mathrm{N}$-amoniacal e ácidos graxos voláteis (AGV) foram analisado no liquido ruminal coletado às $0,2,4,6 \mathrm{e}$ 8 horas após a suplementação com concentrado. As concentrações de pH e N-amoniacal mostraram um efeito linear com a adição de SCAG. Não houve efeito observado para a concentração molar de AGV quando as cabras foram alimentadas com a dieta experimental. Em conclusão, são necessárias mais pesquisas para investigar a adição de SCAG às dietas de cabra, porque há evidências de que o SCAG aumenta o pH ruminal e diminui o excesso de amônia ruminal sem alterar a concentração de AGV no
\end{abstract}

1 Discentes, Programa de Pós-Graduação em Zootecnia, Departamento de Zootecnia, Universidade Estadual de Maringá, UEM, Maringá, PR, Brasil. E-mail: ludmilacoutogomes@gmail.com; anapaula_possamai@hotmail.com; bru_hy@hotmail.com

2 Profs. Drs., Departamento de Zootecnia, UEM, Maringá, PR, Brasil. E-mail: cralcalde@wnet.com.br; jcdamasceno1@gmail. com; rig@wnet.com.br

* Author for correspondence 
liquido ruminal.

Palavras-chave: Ácidos graxos voláteis. Digestibilidade. N-alcanos. Nitrogênio amoniacal.

Suplementação com gordura.

\section{Introduction}

In general, a strategy to increase the concentrate energy content in order to improve the performance of lactating animals is to add to the diet foods that are rich in lipids, such as oilseed grains and/ or oil (cottonseed, soybean, sunflower, linseed, etc.). According to Palmquist (1994), several factors affect this management practice, such as the commercial availability of high quality lipids, increased energy intake when dry matter intake is reduced and the replacement of carbohydrates by lipids to improve grass intake and ruminal fermentation. In addition, lipids improve fatsoluble vitamin absorption, supply fatty acids to the membranes of tissues, act as precursors of metabolic pathways and increase certain fatty acids in milk fat, especially polyunsaturated fatty acids (PALMQUIST; MATTOS, 2011). However, depending on the amount supplied, the degree of unsaturation and the degree of rumen-protected lipid, reduced performance can occur owing to the decreased activity of cellulolytic microorganisms, with a consequent reduction in fiber digestibly (YANG et al., 2009; PALMQUIST; MATTOS, 2011).

The saponification of long chain fatty acids, typically derived from soybean or palm oils, with calcium ions results in calcium salts, a type of rumen-inert fat containing high levels of fatty acids such as palmitic acid (16:0), stearic acid (18:0), oleic acid (18:1) and linoleic acid (18:2); this was originally proposed by Jenkins and Palmquist (1982). Thus, feeding calcium salts of fatty acids (CSFA), which are inert in the rumen, can enhance the energy density of rations and has no negative effects on ruminal fermentation.

CSFA is a complex of calcium ions with long chain fatty acids; the main sources are soybean oil or palm oil, depending on the commercial product. CSFA is inert in the rumen and is dissociated in the acidic conditions of the abomasum. Among the benefits of CSFA is the possibility of increasing the energy content of the diet without influencing fiber digestibility, allowing high levels of inclusion in ruminant diets. In this sense, CSFA are interesting, because they do not change ruminal fermentation (SIROHI et al., 2010). Thus, CSFA is an energy supplement which in combination with other foods can increase dry matter intake, therefore providing good availability of nutrients for satisfactory yields.

The evaluation of a food for ruminants should include the rumen fermentation conditions, which are indicative of the potential of the food in question to promote better performance. However, there is a shortage of information on the effect of CSFA on rumen fermentation in goats in a grassland system. Thus, this study aimed to evaluate the addition of CSFA to concentrate fed to grassland goats on the nutritive value of the diet and rumen fermentation.

\section{Materials and Methods}

The experiment was conducted at an experimental farm at the State University of Maringá, southern Brazil. Five dry empty Boer-Saanen goats with a ruminal cannula and an average body weight 71.4 $\pm 11.8 \mathrm{~kg}$ were distributed in a Latin square design with an experimental period of 21 days, of which 14 days were for adaptation and seven days were for data collection. The Latin square design was $5 \times 5$ with five treatments $(0 \%, 1.5 \%, 3.0 \%, 4.5 \%$ and $6.0 \%$ CSFA).

Pelleted concentrate was composed of ground corn, soybean meal, a mineral-vitamin supplement for goats, salt and rumen-inert fat in the form of CSFA from a commercially available product 
derived from soybean oil (Lactoplus ${ }^{\circledR}$ from Dalquim Chemical Industry Ltd., with 1.94 g.g ${ }^{-1}$ total digestible nutrients, $820 \mathrm{~g} \cdot \mathrm{kg}^{-1}$ ether extract, 100 g.kg-1 calcium, 260 g. $\mathrm{kg}^{-1}$ oleic acid and 420 g.kg-1 linoleic acid); in five levels of inclusion ( $0 \%$, $1.5 \%, 3.0 \%, 4.5 \%$ and $6.0 \%$ of the concentrate) (Table 1). The among of concentrate offered to the goats was established at $1 \mathrm{~kg} . d a y^{-1}$ as feed, i.e. half of the estimated nutritional requirements of Saanen goats (NRC, 2007) with a body weight of $60 \mathrm{~kg}$ and a milk yield of $3.0 \mathrm{~kg}$.day ${ }^{-1}$ with $3.5 \%$ fat. The goats in this rumen fermentation trial were fed with the same diets of the lactation goats' trial.

Table 1. Ingredients and chemical composition of the concentrate.

\begin{tabular}{|c|c|c|c|c|c|}
\hline \multirow{2}{*}{ Composition } & \multicolumn{5}{|c|}{ Level of calcium salts of fatty acids ${ }^{\mathrm{A}}$} \\
\hline & $0.0 \%$ & $1.5 \%$ & $3.0 \%$ & $4.5 \%$ & $6.0 \%$ \\
\hline \multicolumn{6}{|l|}{ Ingredient (g.kg-1 DM) } \\
\hline Ground corn & 695.0 & 676.0 & 658.0 & 639.0 & 621.0 \\
\hline Soybean meal & 280.0 & 284.0 & 287.0 & 291.0 & 294.0 \\
\hline Rumen bypass fat ${ }^{\mathrm{B}}$ & & 15.0 & 30.0 & 45.0 & 60.0 \\
\hline Mineral-vitamin supplement ${ }^{\mathrm{C}}$ & 20.0 & 20.0 & 20.0 & 20.0 & 20.0 \\
\hline Salt & 5.0 & 5.0 & 5.0 & 5.0 & 5.0 \\
\hline \multicolumn{6}{|c|}{ Chemical composition (g.kg-1 DM) } \\
\hline Dry matter $\left(\mathrm{g} \cdot \mathrm{kg}^{-1}\right)$ & 911.5 & 915.6 & 919.8 & 923.8 & 908.7 \\
\hline Organic matter & 961.3 & 957.3 & 961.4 & 952.5 & 950.7 \\
\hline Ash & 38.7 & 42.7 & 38.6 & 47.5 & 49.3 \\
\hline Crude protein & 214.7 & 212.8 & 209.6 & 213.7 & 223.9 \\
\hline Ether extract ${ }^{\mathrm{D}}$ & 25.02 & 36.91 & 48.82 & 60.71 & 72.61 \\
\hline Neutral detergent fibre & 103.60 & 94.04 & 97.55 & 89.34 & 86.92 \\
\hline Non-fibre carbohydrates & 617.9 & 613.6 & 605.4 & 588.7 & 567.3 \\
\hline Total carbohydrates & 721.53 & 707.66 & 702.90 & 678.02 & 654.23 \\
\hline
\end{tabular}

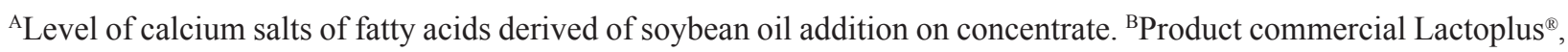
chemical composition: 3.39 Mcal. $\mathrm{kg}^{-1}$ of metabolisable energy, 820 g.kg-1 ${ }^{-1}$ at, 100 g.kg-1 Ca. ${ }^{C}$ Chemical composition (per $\mathrm{kg}$ of Caprinofós $\mathrm{s}^{\circledast}$ with mineral organic): Ca $240 \mathrm{~g}$; P 71 g; F $710 \mathrm{mg}$ (Max); Mg 20 g; K 28.2 g; S 20 g S; Fe 250 mg; Cu 400 mg; Mn 1,350 mg; Zn 1,700 mg; Co 30 mg; I 40 mg; Se 15 mg; Cr 10 mg; Vitamin A 135,000 UI; Vitamin D3 68,000 UI; Vitamin

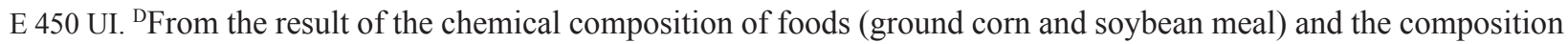
of the Lactoplus ${ }^{\circledR}$ label.

Goats remained in the pasture for approximately seven hours (8:00 am to $3: 30 \mathrm{pm})$ and were housed in single pens for the rest of the day and overnight, where they received the pelleted concentrate. The goats had free access to water in the pasture and pens.

From day 10 to 19 , a cellulose capsule of synthetic paired chain $n$-alkane $\left(\mathrm{C}_{32} \mathrm{H}_{66}\right.$, Dotriacontane, $97 \%$ purity, ref. D223107, Sigma-Aldrich Corp., St Louis, MO, USA) was inserted into the rumen by an oral probe twice daily at 8:00 am and 4:00 pm, supplying a total of $80 \mathrm{mg}$ of $\mathrm{C}_{32} \mathrm{H}_{66}$ /day.

For grazing goats, an area of one hectare (1 ha) was used with Stargrass (Cynodon nlemfuensis) maintained by continuous stocking (1.5 UA.ha ${ }^{-1}$ ) (Table 2), thus other five goats grazed this area. The grassland was fertilized and corrected through physical and chemical analysis of the soil and grass demand. Fertilizer was applied at an N-P-K ratio of $8 \mathrm{~kg} \cdot \mathrm{ha}^{-1}$ nitrogen, $67 \mathrm{~kg} \cdot \mathrm{ha}^{-1}$ phosphorus and 
$70 \mathrm{~kg} \cdot \mathrm{ha}^{-1}$ potassium (200 kg of N-P-K fertilizer 4-20-20; $150 \mathrm{~kg}$ of single superphosphate and 50 $\mathrm{kg}$ of potassium chloride) in September 2011. The grazing period was from June 172012 to September 242012.

Sampling of the forage for chemical analysis and manual separation of morphological components (leaf blades, stems and sheaths, dead material), were collected once in each experimental period; to ensure random sampling, one $1.0 \mathrm{~m}^{2}$ wire square was thrown eight times in the paddock and the grass was cut $15 \mathrm{~cm}$ above the ground. Samples of forage to determine total forage mass were cut close to the soil. The sward height was measured with a wooden ruler graduated in centimeters at 20 random points. For chemical analysis, samples of concentrate were taken during each experimental period and pooled.

Table 2. Chemical composition and forage mass in Stargrass (Cynodon nlemfuensis) of the each experimental period.

\begin{tabular}{|c|c|c|c|c|c|}
\hline & \multicolumn{5}{|c|}{ Period $^{\mathrm{A}}$} \\
\hline & $\mathrm{P} 1$ & $\mathrm{P} 2$ & P3 & P4 & P5 \\
\hline \multicolumn{6}{|l|}{ Chemical (g.kg-1 DM) } \\
\hline Dry matter $\left(\mathrm{g} \cdot \mathrm{kg}^{-1}\right)$ & 306.3 & 312.9 & 370.5 & 451.8 & 391.3 \\
\hline Organic matter & 944.9 & 940.5 & 923.6 & 937.4 & 936.4 \\
\hline Ash & 55.1 & 59.5 & 76.4 & 62.6 & 63.6 \\
\hline Crude protein & 149.8 & 152.4 & 154.7 & 94.6 & 102.3 \\
\hline Ether extract & 22.3 & 18.7 & 15.7 & 17.6 & 14.0 \\
\hline Neutral detergent fibre & 735.7 & 674.6 & 680.2 & 690.6 & 694.4 \\
\hline Non-fibre carbohydrates & 37.1 & 94.9 & 73.0 & 134.6 & 125.6 \\
\hline Total carbohydrates & 772.8 & 769.5 & 753.1 & 825.2 & 820.1 \\
\hline Sward height (cm) & 54.8 & 49.7 & 44.05 & 38.95 & 34.75 \\
\hline \multicolumn{6}{|l|}{ Forage mass (kg.DM.ha-1) } \\
\hline Forage mass & 4273.0 & 4068.1 & 3860.2 & 3448.3 & 3330.6 \\
\hline Forage mass (above $15 \mathrm{~cm}$ ) & 1482.3 & 986.2 & 1506.2 & 1457.8 & 958.2 \\
\hline Leaf blade(kg.DM.ha $\left.{ }^{-1}\right)$ & 534.8 & 266.5 & 442.0 & 444.5 & 323.2 \\
\hline Stem and sheath(kg.DM.ha $\left.{ }^{-1}\right)$ & 737.9 & 369.9 & 522.8 & 593.4 & 306.8 \\
\hline Leaf: Stem ratio & 0.72 & 0.72 & 0.85 & 0.75 & 1.05 \\
\hline
\end{tabular}

ASampling days: P1: 18 June 2012, P2: 8 July 2012, P3: 28 July 2012, P4: 19 August 2012, P5: 6 September 2012.

Individual goat fecal grab samples were taken twice daily at 8:00 am and 4:00 pm from day 15 to 20 and a portion (about $30 \mathrm{~g}$ ) was dried for $72 \mathrm{~h}$ at $55^{\circ} \mathrm{C}$ for later chemical analysis.

Samples of forage and feces from each period were oven-dried $\left(55^{\circ} \mathrm{C}\right.$ for $\left.72 \mathrm{~h}\right)$, then ground through a 1-mm screen in a Wiley mill. The concentrate was ground through a 1-mm screen in a hammer mill. Dry matter was determined according to method $\mathrm{n}^{\circ}$. 934.01 of AOAC(1998). Ash was determined by combustion in a muffle furnace according to method $n^{\circ}$. 942.05 (AOAC, 1998). Calcium and phosphorus were analyzed by using acid digestion with nitric and perchloric acid (1:2). After that, they were filtered to obtain a mineral solution. Calcium and phosphorus readings were obtained by using atomic absorption (spectrophotometer GBC 932 AA in flame air-acetylene) and colorimetric (spectrophotometer Shimadzu UV-1601 UV-Visible Spectrophotometer $\left.{ }^{\mathbb{R}}\right)$, respectively, according to 
(AOAC, 1990). Total nitrogen (TN) was evaluated using a Tecnal TE-036/1 (Tecnal, Piracicaba, São Paulo, Brazil) following AOAC method no. 988.05 (AOAC, 1998) and crude protein (CP) was estimated as TN x 6.25. The ether extract (EE) was assessed using a Tecnal TE-044/1 apparatus according to method no. 920.39 (AOAC, 1998). Neutral detergent fiber (NDF) was evaluated as described by Van Soest et al. (1991) without the use of sodium sulfite and with the inclusion of heatstable $\alpha$-amylase (Alpha-amylase Termamyl 2x, Tecnoglobo ${ }^{\circledR}$, Curitiba, Brazil). Total carbohydrates (TC) and total digestible nutrient (TDN) were estimated according to the equations described by Sniffen et al. (1992): TC (g.kg-1 of DM) $=1000-$ $(\mathrm{CP}+\mathrm{EE}+$ ash $) ; \mathrm{TDN}=\mathrm{dCP}+(2.25 \times \mathrm{dEE})+$ $\mathrm{dTC}$; in which $\mathrm{dCP}=$ digestible crude protein, $\mathrm{dEE}$ $=$ digestible ether extract and $\mathrm{dTC}=$ digestible total carbohydrates. The method used to calculate the feed energy value (Mcal. $\mathrm{kg}^{-1}$ ) using the digestible energy (DE) and metabolizable energy (ME) was done using the following equation (NRC, 2007): $\mathrm{DE}=0.04409 \times \mathrm{TDN}(\%) ; \mathrm{ME}=1.01 \times \mathrm{DE}-0.45$.

On day 21, ruminal fluid was collected manually from different locations within the rumen at 0,2 , 4, $6 \mathrm{~h}$ and $8 \mathrm{~h}$ after concentrate supplementation. Rumen $\mathrm{pH}$ was measured immediately after sample collection with a portable $\mathrm{pH}$ meter (Tecnal, Piracicaba, SP, Brazil). After that, the rumen fluid was then strained through four layers of cheesecloth and two aliquots of strained ruminal fluid were collected.

To determine the ammonia nitrogen concentration $\left(\mathrm{N}-\mathrm{NH}_{3}\right)$, the samples were acidified with $2 \mathrm{~mL}$ of 1:1 sulfuric acid:waterin $100 \mathrm{~mL}$ of each sample and frozen for later determination by the potassium hydroxide $(\mathrm{KOH})$ distillation method described by Preston (1995).

To determine the volatile fatty acid (VFA) concentration, the samples were frozen for later determination. Next, samples of ruminal fluid were centrifuged for $15 \mathrm{~min}$ at $3,500 \mathrm{rpm}$ at $4^{\circ} \mathrm{C}$ and $2 \mathrm{~mL}$ of rumen fluid centrifugate was acidified with $0.4 \mathrm{~mL}$ of formic acid (88\%). VFA analyses were performed according to Palmquist and Conrad (1971) at 0 and $4 \mathrm{~h}$ after concentrate supplementation.

Agas chromatograph (SHIMADZU, GC-2014®) equipped with an autoinjector SHIMADZU, AOC $\left.20 \mathrm{i}{ }^{\circledR}\right)$ was used to quantify the VFA. The column used was a $19091 \mathrm{~N}$, HP-INNOWax GC Column (Agilent Technologies ${ }^{\circledR}, 30 \mathrm{~m} \times 0.32 \mathrm{~mm} \times 0.50$ $\mu \mathrm{m})$. The carrier gas was nitrogen at a constant flux of $3.18 \mathrm{~mL} / \mathrm{min}$. Temperature gradients were controlled for the injector $\left(200^{\circ} \mathrm{C}\right)$ and the column $\left(80^{\circ} \mathrm{C}\right.$ for $3 \mathrm{~min}$ and $20^{\circ} \mathrm{C} / \mathrm{min}$ to $\left.240^{\circ} \mathrm{C}\right)$. The $\mathrm{GC}$ detector temperature was set to $250^{\circ} \mathrm{C}$. With a microliter syringe, $1 \mu \mathrm{L}$ of the sample was injected with a split ratio of 1:10.

The extraction and determination of the n-alkane content in forage and feces were determined according to the method of Mayes et al. (1986) modified by Vulich et al. (1995) based on the direct saponification of samples.

A gas chromatograph (GC Agilent 7890A®) equipped with a mass selective detector (MS Agilent 5975C®) was used to identify and quantify the $n$-alkanes. The column used was a Zebron $^{\mathrm{TM}} \mathrm{ZB}-5 \mathrm{MS}(30 \mathrm{~m} \times 0.32 \mathrm{~mm} \times 0.25 \mu \mathrm{m}$, absorbent composed of 5\% phenyl-arylene- $95 \%$ polydimethylsiloxane). The carrier gas was $\mathrm{H}_{2}$ at a constant flux of $1 \mathrm{~mL} / \mathrm{min}$. Temperature gradients were controlled for the injector $\left(300^{\circ} \mathrm{C}\right)$ and the column $\left(130^{\circ} \mathrm{C}\right.$ for $1 \mathrm{~min}, 10^{\circ} \mathrm{C} / \mathrm{min}$ to $210^{\circ} \mathrm{C}$ and $5^{\circ} \mathrm{C} / \mathrm{min}$ to $310^{\circ} \mathrm{C}$ with a hold of $1 \mathrm{~min} ; 32 \mathrm{~min}$ ). The MS source temperature was set at $250^{\circ} \mathrm{C}$ and the temperature of the MS quadrupole was $120^{\circ} \mathrm{C}$. With a microliter syringe, $1 \mu \mathrm{L}$ of the sample was injected with a split ratio of 1:10.

The gas chromatograph process was calibrated with an external standard solution of a synthetic n-alkane mix including $\mathrm{C}_{24}, \mathrm{C}_{26}, \mathrm{C}_{28}, \mathrm{C}_{32}, \mathrm{C}_{34}$ and $\mathrm{C}_{36}$ (Tetracosane by $99 \%$ purity ref. no. T8752, Hexacosane by $99 \%$ purity ref $n$ no. 241687 , 
Dotriacontane by $97 \%$ purity ref. no. D223107, Tetratriacontane by $98 \%$ purity ref. no. 287261 , Hexatriacontane by $98 \%$ purity ref. no. 52919; Sigma-Aldrich Corp., St Louis, MO, USA). The chromatography peak areas corresponding to each n-alkane were determined by MSD ChemStation Data Analysis ${ }^{\circledR}$. The identified peaks were converted to the n-alkane quantity in reference to each peak area and the internal standard $\mathrm{C}_{34}$, and then calculated into $\mathrm{mg} . \mathrm{g}^{-1}$ of DM.

The dry matter intake (DMI) was estimated by the n-alkane concentration in forage and feces naturally present in the diet $\left(\mathrm{C}_{31}\right.$ and $\left.\mathrm{C}_{33}\right)$ and the homologue $\mathrm{C}_{32}$, which was orally administered. The estimated values of DMI with the pairs $\mathrm{C}_{31}: \mathrm{C}_{32}$ and $\mathrm{C}_{33}: \mathrm{C}_{32}$ were obtained by the Mayes et al. (1986) equation: $\mathrm{DMI}=\left[\left(\mathrm{F}_{\mathrm{i}} / \mathrm{F}_{\mathrm{p}}\right) * \mathrm{D}_{\mathrm{p}}\right] /\left[\mathrm{H}_{\mathrm{i}}-\left(\mathrm{Fi} / \mathrm{F}_{\mathrm{p}}\right) * \mathrm{H}_{\mathrm{p}}\right] * 100$; where: $\mathrm{DMI}=$ dry matter intake $\left(\mathrm{kg} \mathrm{MS}\right.$ day $\left.^{-1}\right) ; \mathrm{F}_{\mathrm{i}}=$ $n$-alkane of unpaired chain $\left(\mathrm{C}_{31}\right.$ or $\left.\mathrm{C}_{33}\right)$ content (mg. $\left.\mathrm{kg}^{-1} \mathrm{MS}\right)$ in feces; $\mathrm{F}_{\mathrm{p}}=n$-alkane of paired chain $\left(\mathrm{C}_{32}\right)$ content in feces; $\mathrm{D}_{\mathrm{p}}=$ quantity $(\mathrm{mg})$ of synthetic $n$-alkane of paired chain $\left(\mathrm{C}_{32}\right)$ fed; $\mathrm{H}_{\mathrm{i}}=$ natural $n$-alkane of unpaired chain $\left(\mathrm{C}_{31}\right.$ or $\left.\mathrm{C}_{33}\right)$ content in forage, $\mathrm{H}_{\mathrm{p}}=$ natural $n$-alkane of paired chain $\left(\mathrm{C}_{32}\right)$ in forage. The DM digestibility was estimated by the equation: DMD = 1-(ID/IF) x 100 where: DMD = dry matter digestibility coefficient by n-alkane, ID $=$ internal content of n-alkane in forage, and IF = internal content of $n$-alkane in feces.

The data were analyzed using the Statistical Package for the Social Sciences (IBM SPSS Statistics, version 22, Chicago, IL) by analysis of variance, linear curve estimation and the quadratic of the regression equations $(\alpha=0.05)$, with the general model: $\mathrm{Y}_{\mathrm{ijkl}}=\mu+\mathrm{T}_{\mathrm{i}}+\mathrm{P}_{\mathrm{j}}+\mathrm{A}_{\mathrm{l}}+\mathrm{e}_{\mathrm{ij}}$ where: $\mathrm{Y}_{\mathrm{ijkl}}$ $=$ the dependent variable, $\mu=$ general constant; $\mathrm{D}_{\mathrm{i}}=$ effect of concentrate diet $i ; \mathrm{P}_{\mathrm{j}}=$ effect of period $j ; \mathrm{Al}$ $=$ effect of animal $l ; \mathrm{e}_{\mathrm{ijkl}}=$ random error. The critical points of the quadratic equations $\left(\mathrm{Y}=\mathrm{c}+\mathrm{bx}+\mathrm{ax}^{2}\right)$ were found using the definition of the derivative, where $X=-b /(2 x a)$, and $Y=-\left(b^{2}\right) /(4 \times a)$.

\section{Results and Discussion}

There was no significant effect on the intake of dry matter, organic matter, crude protein, neutral detergent fiber, total carbohydrates and total digestible nutrients in goats fed the concentrate with CSFA after grazing. However, the ether extract intake was linearly increased with the addition of CSFA in the concentrate. The digestibility coefficients of dry matter, organic matter, neutral detergent fiber, total carbohydrates and non-fiber carbohydrates were not changed by the treatments. However, the significant effect of the ether extract digestibility coefficients did not enhance the energy values of diets, including total digestible nutrients, digestible energy, metabolizable energy and net energy for lactation (Table 3).

The dry matter and nutrient intake were not modified by the addition of CSFA to the concentrate for goats grazing in a Stargrass pasture, which was $1.81 \mathrm{~kg}$.day ${ }^{-1}$ for DMI. Molina (2013) also showed $2.0 \mathrm{~kg}^{- \text {day }^{-1}}$ for the DMI of Saanen goats fed with $0,6.25,12.50,18.75$ and 25.00 g. $\mathrm{kg}^{-1}$ of CSFA. When compared to other studies, in which the goats were raised on grassland systems, the results are in agreement. Rufino et al. (2012) supplemented with $1.5 \%$ of body weight in Anglo-Nubian goats grazed on a Tanzania-grass grassland and showed 1.89 ${\mathrm{kg} . \text { day }^{-1}}^{1}$ for DMI. Mancilla-Leytón et al. (2013) observed $1.87 \mathrm{~kg}^{\text {day }}{ }^{-1}$ for DMI when goats were supplemented with $0.5 \mathrm{~kg}^{- \text {day }^{-1}}$ of concentrate in scrublands (158.8 g.kg-1 CP and 579.4 g.kg-1 NDF).

The mean dry matter digestibly (DMD) in this study for goats was $0.64 \mathrm{~g} \cdot \mathrm{g}^{-1}$. Silva et al. (2007) and Molina (2013) showed values of 0.63 g.g $\mathrm{g}^{-1}$ and 0.65 g. $\mathrm{g}^{-1}$, respectively. Higher values were found by Sanz Sampelayo et al. (2002) who showed a mean DMD of 0.69 g.g $\mathrm{g}^{-1}$ and Souza et al. (2014) who showed a mean DMD value of $0.70 \mathrm{~g} . \mathrm{g}^{-1}$. The lower DMI may be related to the low $\mathrm{pH}$ rumen observed (5.83 to 6.0) in all treatments, and is a factor that may reduce cellular division and cellulolytic bacterial growth, which would lead to cellular wall 
degradation (VAN SOEST, 1994). The continuous grazing management used in this experiment influences the pasture structure and composition, consequently affects animal performance. Thus, the amount of leaf blade available (31.3\% of total forage mass) and the neutral detergent fiber content (mean of $\left.695 \mathrm{~g} . \mathrm{kg}^{-1}\right)$ in the forage can also contributes for the lower DMI.

Table 3. Dry matter and nutrients intake and total apparent digestibility of goats in grassland fed by experimental diets.

\begin{tabular}{|c|c|c|c|c|c|c|c|}
\hline & \multicolumn{5}{|c|}{ Level of calcium salts of fatty acids ${ }^{\mathrm{A}}$} & \multirow[b]{2}{*}{ SE } & \multirow[b]{2}{*}{ P-value } \\
\hline & $0.0 \%$ & $1.5 \%$ & $3.0 \%$ & $4.5 \%$ & $6.0 \%$ & & \\
\hline Body weight $(\mathrm{kg})$ & 72.01 & 70.02 & 73.15 & 70.81 & 71.16 & 11.79 & 0.18 \\
\hline Metabolic body weight $\left(\mathrm{BW}^{0.75}\right)$ & 24.65 & 24.13 & 24.97 & 24.36 & 24.43 & 2.50 & 0.23 \\
\hline \multicolumn{8}{|l|}{ Dry matter intake $\left(\mathrm{kg} \cdot \mathrm{day}^{-1}\right)$} \\
\hline Total DMI & 1.69 & 1.75 & 1.87 & 1.91 & 1.83 & 0.06 & 0.12 \\
\hline Forage DMI & 0.77 & 0.83 & 0.95 & 0.98 & 0.92 & 0.06 & 0.14 \\
\hline Concentrate DMI & 0.92 & 0.92 & 0.92 & 0.93 & 0.91 & & \\
\hline Total DMI (g. $\mathrm{kg}^{-1}$ of BW) & 23.47 & 24.99 & 25.56 & 26.97 & 25.72 & 0.53 & 0.13 \\
\hline Total DMI (g.kg-1 of BW $\left.{ }^{0.75}\right)$ & 69.34 & 74.30 & 75.63 & 79.19 & 77.15 & 3.75 & 0.45 \\
\hline \multicolumn{8}{|l|}{ Nutrient intake (kg.day $\left.{ }^{-1}\right)$} \\
\hline Organic matter & 1.60 & 1.66 & 1.77 & 1.80 & 1.73 & 0.06 & 0.13 \\
\hline Crude protein & 0.30 & 0.30 & 0.32 & 0.33 & 0.32 & 0.01 & 0.08 \\
\hline Ether extract & 0.04 & 0.05 & 0.06 & 0.07 & 0.08 & 0.00 & $<0.00^{\mathrm{C}}$ \\
\hline Neutral detergent fibre & 0.63 & 0.66 & 0.75 & 0.77 & 0.72 & 0.04 & 0.18 \\
\hline Total carbohydrates & 1.27 & 1.30 & 1.40 & 1.40 & 1.33 & 0.05 & 0.26 \\
\hline Non-fibre carbohydrates & 0.64 & 0.64 & 0.65 & 0.64 & 0.63 & 0.01 & 0.10 \\
\hline Total digestible nutrients & 1.04 & 1.20 & 1.22 & 1.30 & 1.17 & 0.06 & 0.09 \\
\hline \multicolumn{8}{|l|}{ Digestibility coefficient $\left(\mathrm{g} \cdot \mathrm{g}^{-1}\right)$} \\
\hline Dry matter & 0.60 & 0.69 & 0.64 & 0.67 & 0.62 & 0.03 & 0.22 \\
\hline Organic matter & 0.64 & 0.72 & 0.68 & 0.71 & 0.67 & 0.02 & 0.23 \\
\hline Crude protein & 0.55 & 0.66 & 0.60 & 0.66 & 0.60 & 0.03 & 0.14 \\
\hline Ether extract & 0.50 & 0.67 & 0.70 & 0.78 & 0.78 & 0.04 & $<0.00^{\mathrm{D}}$ \\
\hline Neutral detergent fibre & 0.50 & 0.60 & 0.58 & 0.62 & 0.57 & 0.04 & 0.29 \\
\hline Total carbohydrates & 0.67 & 0.73 & 0.70 & 0.72 & 0.68 & 0.02 & 0.30 \\
\hline Non-fibre carbohydrates & 0.83 & 0.83 & 0.84 & 0.83 & 0.80 & 0.01 & 0.12 \\
\hline \multicolumn{8}{|l|}{ Energy values of diets $\left(\right.$ Mcal. $\left.\mathrm{kg}^{-1}\right)$} \\
\hline Total digestible nutrients (g. $\mathrm{g}^{-1}$ ) & 0.62 & 0.69 & 0.65 & 0.68 & 0.66 & 0.02 & 0.24 \\
\hline Digestible energy $^{\mathrm{B}}$ & 2.72 & 3.02 & 2.88 & 2.99 & 2.82 & 0.10 & 0.24 \\
\hline Metabolizable energy ${ }^{\mathrm{B}}$ & 2.29 & 2.60 & 2.45 & 2.57 & 2.40 & 0.10 & 0.24 \\
\hline
\end{tabular}

${ }^{\mathrm{A}} \mathrm{Level}$ of calcium salts of fatty acids derived of soybean oil addition on concentrate.

${ }^{\mathrm{B}}$ Estimated by NRC (2007) equations.

${ }^{\mathrm{C}} \mathrm{Y}=0.04+0.008 \mathrm{x}, \mathrm{r}^{2}=0.99$.

${ }^{\mathrm{D}} \mathrm{Y}=0.55+0.044 \mathrm{x}, \mathrm{r}^{2}=0.99$. 
The linear positive effect on ether extract intake (EEI) for goats fed with the concentrate containing CSFA is explained by the ether extract (EE) content in the concentrate (Table 1). The addition of 15 grams of CSFA to the concentrates increases the content of EE by 11.9 g. $\mathrm{kg}^{-1}$. This same effect, i.e. linear positive, was observed for the ether extract digestibility coefficient. This effect may be associated with the higher concentration of unsaturated fatty acids in CSFA available in the intestine, which have higher solubility in micelles, and thus are more digestible compared to fatty acids with a higher degree of saturation (PALMQUIST; MATTOS, 2011).

The addition of CSFA to concentrate rations for grazing goats not changed the neutral detergent fiber digestibility (NDFD); however, this result shows that forms of rumen-inert lipids cannot decrease cell wall digestibility, supported by studies by Molina (2013), Sanz Sampelayo et al. (2002) and Souza et al. (2014).Thus, calcium salts of fatty acids is a feed that can be used strategically in the ruminants diet, however for the decision of including this feed should also be considered economic aspects.

The rumen $\mathrm{pH}$ was linearly increased with CSFA inclusion in the goat diet. Although the optimal $\mathrm{pH}$ range ( $\mathrm{pH} 6.2$ to 7.0 ) was not maintained, CSFA addition may be a strategy for goat diet substitution rather than starch, as it does not negatively influence rumen $\mathrm{pH}$. Future researches should assess the effects of calcium salts of fatty acids associate with buffer agents that may result in an increase in $\mathrm{pH}$ and a better utilization of dietary fiber.

Although the low $\mathrm{pH}$ rumen observed (5.83 to 6.0) in all treatments was not appropriate for cellulolytic microorganisms, the microorganisms fixation in the fiber portion of food was not inhibited. According to Van Soest (1994), low pH (inferior to 6.2) is a factor that may reduce cellular division and cellulolytic bacterial growth, which would lead to cellular wall degradation. However, in this study, the low $\mathrm{pH}$ values did not reduce the neutral detergent fiber digestibility, which can be explained due to due to the period that the ruminal $\mathrm{pH}$ remained below 6.2. This low $\mathrm{pH}$ was explained by the concentrate ratio in the diet, which was $51 \%$, and also by the time at which rumen fluid samples were collected, i.e. after concentrate ration feeding.

The negative linear response of ruminal ammonia nitrogen $\left(\mathrm{N}-\mathrm{NH}_{3}\right)$ explains $92 \%\left(\mathrm{r}^{2}=\right.$ 0.92) of the results, which ranged between 27.1 to 32.0 mg.dL ${ }^{-1}$. According to Doreau and Ferlay (1995), this reduction in the $\mathrm{N}-\mathrm{NH}_{3}$ content in the rumen is one of the major characteristics of ruminal defaunation. In addition, these results may be linked to the relationship between protein and available energy for ruminal fermentation, as $23.5 \mathrm{mg} . \mathrm{dL}^{-1}$ of $\mathrm{N}^{-\mathrm{NH}_{3}}$ is necessary for the maximum ruminal fermentation rate (MEHREZ et al., 1977).

Lana et al. (2007) supplemented goats with soybean oil at levels of $0 \%, 1.5 \%, 3.0 \%, 4.5,6.0 \%$ and $7.5 \%$ of diet dry matter and observed inferior values (15.77 mg.dL $\left.{ }^{-1} \mathrm{~N}-\mathrm{NH}_{3}\right)$ compared to our study. However, Silva et al. (2007) observed 31.06 mg.dL ${ }^{-1}$ of ruminal $\mathrm{N}^{-N_{3}}$ by adding $5 \%$ CSFA to goat diets. The values of this study are probably related to the diet composition, which affected $\mathrm{N}-\mathrm{NH}_{3}$ availability in the rumen, and also to the high concentrate content in the diets needed to provide $50 \%$ of goat requirements, thus increasing the action of microorganisms and consequently the ammoniac nitrogen values in the rumen. Consequently, the relationship between protein and available energy for ruminal fermentation changed, as microorganisms are unable to use fat as a source of energy for growth (ARCURI et al., 2011). The high ammonia value in rumen can be associated with a decrease in the efficiency of nitrogen utilization to synthetize microbial proteins. According to Rapetti and Bava (2008), in a situation where energy is a limiting factor, an increase in amino acid deamination by microorganisms can occur in the rumen as the bacteria subsequently ferment the carbon skeletons as a source of energy. 
The $\mathrm{pH}$ and ammonia $\mathrm{N}$ concentration in the rumen fluid showed a linear effect with CSFA addition (Table 4 and Figure 1). However, according to the quadratic equations for $\mathrm{pH}$ and ammonia $\mathrm{N}$ as a function of time after feeding with each concentrate (Table 5), the lowest $\mathrm{pH}$ value of the rumen fluid was 5.5 and occurred at $5 \mathrm{~h} 33 \mathrm{~min}$ after feeding with the $1.5 \%$ concentrate, and for ammonia $\mathrm{N}$, the maximum value was $37.05 \mathrm{mg}^{\mathrm{dL}} \mathrm{dL}^{-1} 4 \mathrm{~h} 27$ min after feeding with the $1.5 \%$ concentrate. The peak ammonia concentration occurred between $3 \mathrm{~h}$ 39 min and 4 h 27 min after concentrate feeding.

The $\mathrm{pH}$ curve presented an inverse pattern to the ammonia content, in agreement with Lana et al. $(2005,2007)$, in which goats received oil soybean and propolis extract in the diet. The lowest $\mathrm{pH}$ values occurred at $6 \mathrm{~h} 30 \mathrm{~min}$ after feeding, whereas the highest value of ammonia occurred $4 \mathrm{~h}$ after feeding with the concentrate, which suggests fast activity of fermenter bacteria with the concentrate.

Table 4. Rumen fermentation characteristics after grazing and concentrate feeding ( 0 to 8 hours) of goats in grassland fed by experimental diets.

\begin{tabular}{llllllll}
\hline & \multicolumn{9}{l}{ Level of calcium salts of fatty acids $^{\mathrm{A}}$} & \multirow{2}{*}{ SE } & \multirow{2}{*}{ P-value } \\
\hline & $0.0 \%$ & $1.5 \%$ & $3.0 \%$ & $4.5 \%$ & $6.0 \%$ & & \\
\hline $\mathrm{pH}$ & 5.79 & 5.74 & 6.11 & 5.95 & 5.97 & 0.04 & $<0.01 \mathrm{~B}$ \\
Amonia N $\left(\mathrm{mg}_{\mathrm{n}} \mathrm{dL} \mathrm{dL}^{-1}\right)$ & 30.75 & 32.02 & 32.19 & 27.08 & 28.28 & 1.04 & $<0.01 \mathrm{C}$ \\
\hline
\end{tabular}

${ }^{\mathrm{A}} \mathrm{Level}$ of calcium salts of fatty acids derived of soybean oil addition on concentrate.

${ }^{\mathrm{B}}$ Regression equation: $\mathrm{Y}=5.81+0.03 \mathrm{x} . \mathrm{r}^{2}=0.56$.

${ }^{\mathrm{C}}$ Regression equation: $\mathrm{Y}=32.04-0.66 \mathrm{x} . \mathrm{r}^{2}=0.48$

Figure 1. Ammonia nitrogen and $\mathrm{pH}$ curves in rumen fluid after grazing and in function of time after fed for each concentrate containing calcium salts of fatty acids derived of soybean oil.
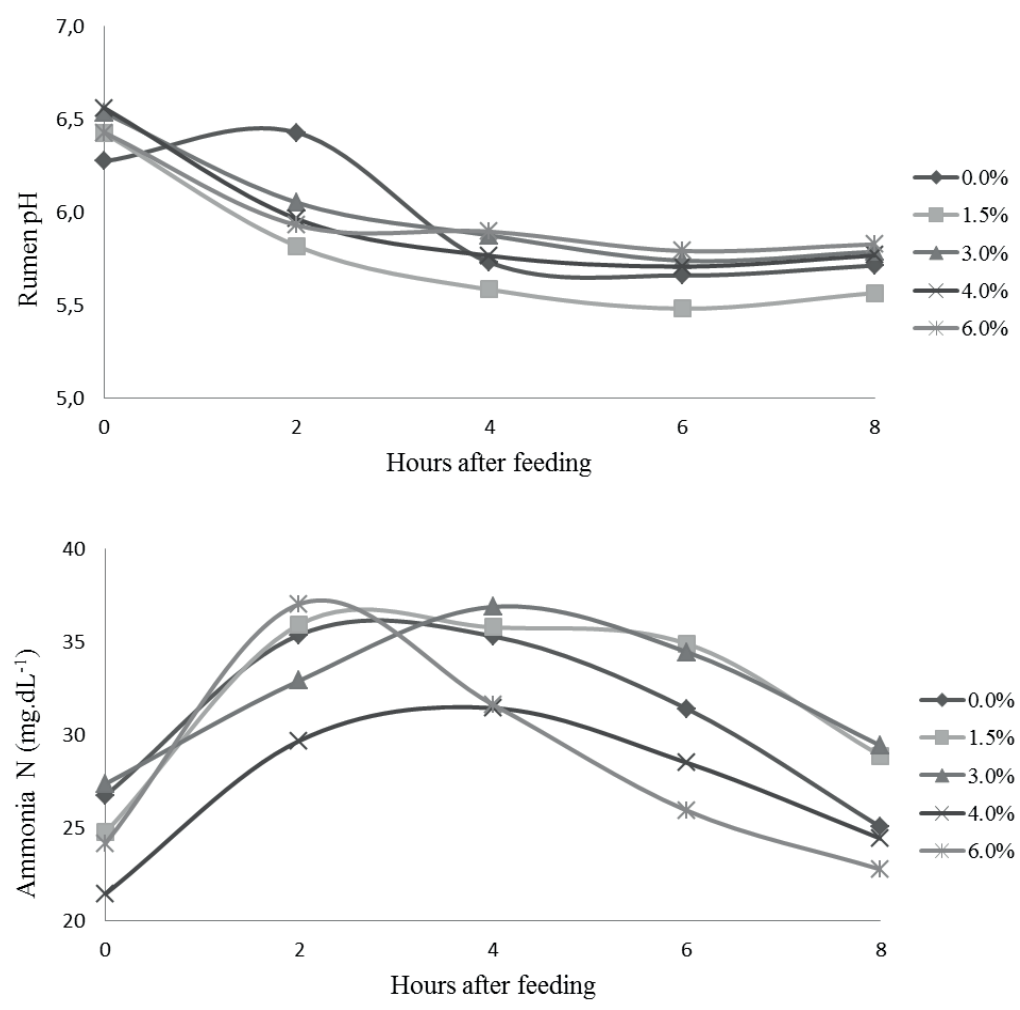
Table 5. Regression equations and critical point obtained for pHammonia $\mathrm{N}\left(\mathrm{mg}^{\mathrm{dL}} \mathrm{LL}^{-1}\right)$ and in function of time after fed for each concentrate.

\begin{tabular}{llll}
\hline Concentrate $^{\mathrm{A}}$ & Regression equation; $\mathrm{r} 2$ & min. $\mathrm{pH}$ & Time (hours) \\
\hline $0.0 \%$ & $\mathrm{Y}=6.23-0.22 \mathrm{x}+0.02 \times 2 ; \mathrm{r} 2=0.94$ & 5.63 & $5 \mathrm{~h} 50$ \\
$1.5 \%$ & $\mathrm{Y}=6.40-0.32 \mathrm{x}+0.03 \times 2 ; \mathrm{r} 2=0.99$ & 5.55 & $5 \mathrm{~h} 33$ \\
$3.0 \%$ & $\mathrm{Y}=6.51-0.25 \mathrm{x}+0.02 \times 2 ; \mathrm{r} 2=0.99$ & 5.73 & $6 \mathrm{~h} 25$ \\
$4.5 \%$ & $\mathrm{Y}=6.53-0.30 \mathrm{x}+0.03 \times 2 ; \mathrm{r} 2=0.98$ & 5.78 & $5 \mathrm{~h} 00$ \\
$6.0 \%$ & $\mathrm{Y}=6.38-0.21 \mathrm{x}+0.02 \times 2 ; \mathrm{r} 2=0.93$ & 5.83 & $5 \mathrm{~h} 25$ \\
\hline Concentrate $^{\mathrm{A}}$ & Regression equation; $\mathrm{r} 2$ & max. Amonia N & Time (hours) \\
\hline $0.0 \%$ & $\mathrm{Y}=27.39+4.46 \mathrm{x}-0.60 \times 2 ; \mathrm{r} 2=0.96$ & 35.68 & $3 \mathrm{~h} 72$ \\
$1.5 \%$ & $\mathrm{Y}=25.56+5.38 \mathrm{x}-0.63 \times 2 ; \mathrm{r} 2=0.93$ & 37.05 & $4 \mathrm{~h} 27$ \\
$3.0 \%$ & $\mathrm{Y}=27.12+4.22 \mathrm{x}-0.49 \times 2 ; \mathrm{r} 2=0.96$ & 36.21 & $4 \mathrm{~h} 31$ \\
$4.5 \%$ & $\mathrm{Y}=21.93+4.43 \mathrm{x}-0.52 \times 2 ; \mathrm{r} 2=0.96$ & 31.37 & $4 \mathrm{~h} 26$ \\
$6.0 \%$ & $\mathrm{Y}=26.44+3.93 \mathrm{x}-0.58 \times 2 ; \mathrm{r} 2=0.67$ & 33.10 & $3 \mathrm{~h} 39$ \\
\hline
\end{tabular}

${ }^{\mathrm{A}} \mathrm{Level}$ of calcium salts of fatty acids derived of soybean oil addition on concentrate.

No effect was observed for total volatile fatty acids, the molar concentrations of acetate, propionate, butyrate, isobutyrate, valerate, isovalerate or the acetate:propionate ratio in rumen fluid zero hours and four hours after feeding with the experimental concentrate (Table 6 and Figure 2 ). However, the values observed four hours after feeding with the concentrate were $69 \%$ higher than those observed at zero hours.

The average values observed for the concentration (mmol.L-1) of volatile fatty acids (VFA) in ruminal fluid before feeding with the concentrate were 61.88 total VFA, 42.11 acetate, 10.39 propionate, 6.82 butyrate, 0.62 isobutyrate, 0.78 valerate, 1.16 isovalerate and 3.81 for the acetate:propionate ratio. Four hours after feeding with the concentrate, the average values were 108.93 total VFA, 66.48 acetate, 25.00 propionate, 13.89 butyrate, 0.58 isobutyrate, 1.60 valerate, 1.39 isovalerate and 2.79 for the acetate:propionate ratio.

It was observed that there were differences in the concentrations of VFA as a function of time $(0 \mathrm{~h}$ and $4 \mathrm{~h}$ ); 4 hours after feeding with the concentrate, the total VFA production increased due to an increase in propionate, butyrate and valerate. However, acetate production was decreased due to impaired production by cellulolytic bacteria, whose ruminal population was decreased owing to the high amount of concentrate in the diet. Li et al. (2014) assessed the effects of dietary effective fiber on rumen degradable starch ratios and rumen fermentation in dairy goats receiving diets with a forage to concentrate ratio of 50:50; these authors reported $64.4 \mathrm{~mol}^{1} 100 \mathrm{~mol}^{-1}$ of acetate and $18.2 \mathrm{~mol}^{-100 \mathrm{~mol}^{-}}$ ${ }^{1}$ of propionate, values similar to those observed in this study.

Data in literature reports variable results on the effect of supplementation with CSFA on rumen VFA production in ruminants. For example, Grummer (1988) reported that ruminal $\mathrm{pH}$, total VFA, and the molar concentrations of acetate and propionate were not affected by fat supplementation with calcium salts of palm oil fatty acids $\left(680 \mathrm{~g}^{\text {. day }}{ }^{-1}\right)$ or prilled fat ( 680 or 910 g.day ${ }^{-1}$ ) for Holstein cows fed a basal diet containing $45 \%$ concentrate, $27.5 \%$ alfalfa silage and $27.5 \%$ corn silage (DM basis). Cenkvári et al. (2005) reported that when sheep were fed a diet composed of alfalfa hay and concentrate and supplemented with 75 g.day $^{-1}$ of calcium salts of linseed oil (5.4\% of dry matter), the total VFA concentration in the rumen fluid measured $3 \mathrm{~h}$ after 
feeding did not change, the acetate:propionate cows with 400 g.day ${ }^{-1}$ of CSFA had decreased total ratio decreased and the butyrate and valerate levels VFA $2 \mathrm{~h}$ after feeding with CSFA. increased. Shibata et al. (2011) reported that fed

Table 6. Volatile fatty acids (VFA) concentration (mmol.L-1) and proportions (mol.100 mol-1) in rumen fluid after grazing of goats fed by experimental diets.

\begin{tabular}{|c|c|c|c|c|c|c|c|}
\hline & \multicolumn{5}{|c|}{ Level of calcium salts of fatty acids ${ }^{\mathrm{A}}$} & \multirow[b]{2}{*}{ SE } & \multirow{2}{*}{$P$-value } \\
\hline & $0.0 \%$ & $1.5 \%$ & $3.0 \%$ & $4.5 \%$ & $6.0 \%$ & & \\
\hline \multicolumn{8}{|c|}{ Before fed with concentrate } \\
\hline Total VFA (mmol.L $\left.\mathrm{L}^{-1}\right)$ & 59.32 & 64.79 & 62.47 & 59.13 & 63.71 & 5.04 & 0.90 \\
\hline Acetate & 38.97 & 45.36 & 41.93 & 40.56 & 43.74 & 3.97 & 0.80 \\
\hline Propionate & 10.08 & 10.64 & 10.60 & 10.02 & 10.63 & 1.01 & 0.98 \\
\hline Butyrate & 7.18 & 6.43 & 7.34 & 6.24 & 6.91 & 0.64 & 0.71 \\
\hline Isobutyrate & 0.59 & 0.60 & 0.64 & 0.62 & 0.65 & 0.10 & 0.99 \\
\hline Valerate & 1.37 & 0.66 & 0.68 & 0.59 & 0.58 & 0.28 & 0.28 \\
\hline Isovalerate & 1.14 & 1.10 & 1.27 & 1.10 & 1.20 & 0.18 & 0.96 \\
\hline \multicolumn{8}{|l|}{$\operatorname{VFA}\left(\mathrm{mol} .100 \mathrm{~mol}^{-1}\right)$} \\
\hline Acetate & 63.76 & 69.92 & 67.02 & 68.07 & 68.15 & 1.71 & 0.20 \\
\hline Propionate & 16.69 & 16.13 & 17.21 & 16.84 & 16.95 & 1.01 & 0.96 \\
\hline Butyrate & 13.39 & 10.13 & 11.52 & 10.97 & 11.01 & 1.27 & 0.49 \\
\hline Isobutyrate & 1.00 & 0.97 & 1.06 & 1.10 & 1.04 & 0.13 & 0.96 \\
\hline Valerate & 3.15 & 1.06 & 1.11 & 1.05 & 0.93 & 0.88 & 0.38 \\
\hline Isovalerate & 2.02 & 1.80 & 2.08 & 1.97 & 1.92 & 0.24 & 0.94 \\
\hline Acetate:propionate & 3.81 & 4.43 & 3.98 & 4.05 & 4.09 & 0.29 & 0.66 \\
\hline \multicolumn{8}{|c|}{4 hours after fed with concentrate } \\
\hline Total VFA $\left(\mathrm{mmol} . \mathrm{L}^{-1}\right)$ & 99.50 & 110.10 & 113.47 & 111.65 & 109.94 & 10.31 & 0.88 \\
\hline Acetate & 59.21 & 66.29 & 70.21 & 69.98 & 66.70 & 5.64 & 0.66 \\
\hline Propionate & 23.03 & 25.49 & 25.04 & 25.16 & 26.26 & 3.54 & 0.97 \\
\hline Butyrate & 13.37 & 14.81 & 14.48 & 13.32 & 13.46 & 2.00 & 0.97 \\
\hline Isobutyrate & 0.54 & 0.54 & 0.64 & 0.56 & 0.63 & 0.11 & 0.92 \\
\hline Valerate & 2.08 & 1.49 & 1.58 & 1.39 & 1.46 & 0.28 & 0.46 \\
\hline Isovalerate & 1.27 & 1.49 & 1.52 & 1.24 & 1.43 & 0.24 & 0.88 \\
\hline \multicolumn{8}{|l|}{$\operatorname{VFA}\left(\mathrm{mol} .100 \mathrm{~mol}^{-1}\right)$} \\
\hline Acetate & 56.00 & 60.06 & 62.11 & 63.13 & 61.09 & 2.76 & 0.44 \\
\hline Propionate & 21.86 & 22.84 & 22.59 & 22.30 & 23.63 & 2.06 & 0.98 \\
\hline Butyrate & 16.96 & 13.58 & 12.11 & 11.73 & 12.13 & 2.59 & 0.61 \\
\hline Isobutyrate & 0.54 & 0.56 & 0.53 & 0.50 & 0.57 & 0.08 & 0.99 \\
\hline Valerate & 3.33 & 1.40 & 1.39 & 1.24 & 1.30 & 0.81 & 0.35 \\
\hline Isovalerate & 1.31 & 1.57 & 1.28 & 1.10 & 1.28 & 0.21 & 0.64 \\
\hline Acetate:propionate & 2.64 & 2.75 & 2.85 & 2.96 & 2.73 & 0.30 & 0.95 \\
\hline
\end{tabular}

${ }^{\mathrm{A}}$ Level of calcium salts of fatty acids derived of soybean oil addition on concentrate. 
However, in the present study, no changes in the molar concentration and proportion of VFA in the rumen fluid were observed. This may indicate that CSFA from soybean oil do not influence ruminal fermentation. This can be explained by the CSFA level, i.e. $0 \%, 1.5 \%, 3.0 \%, 4.5 \%$ and $6.0 \%$ CSFA in the concentrate delivered $\mathrm{EE}$ at approximately $2.37 \%, 2.86 \%, 3.20 \%, 3.67 \%$ and $4.37 \%$ of the DM content in the daily rations; the ether extract level may not have been sufficient to significantly alter rumen fermentation.

Figure 2. Volatile fatty acid proportion in rumen fluid after grazing of goats in grassland fed by experimental diets. (a) before fed with concentrate; (b) 4 hours after fed with concentrate.

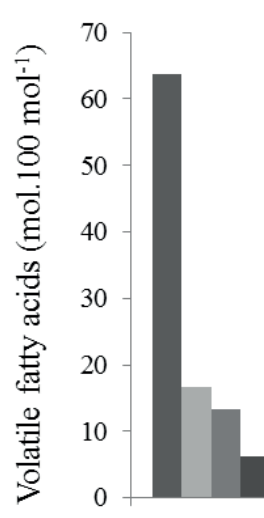

0.0

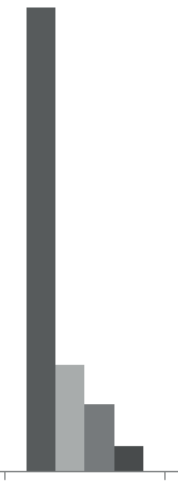

1.5

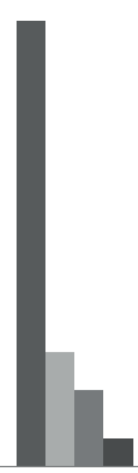

3.0

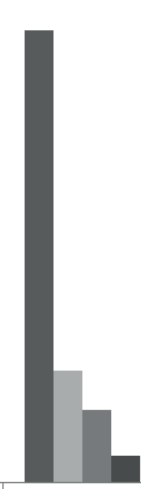

4.5

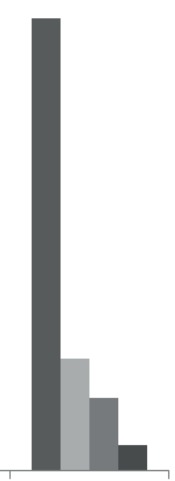

6.0

Level of calcium salts of fatty acids (\%)

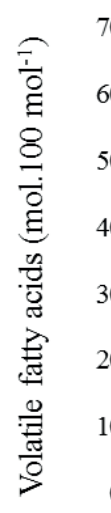

(a)
- Acetate

= Propionate

- Butyrate

- Others VFA

(b)

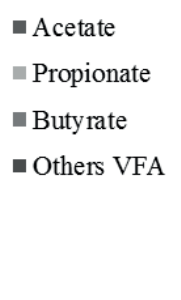

- Acetate

Propionate

- Butyrate

- Others VFA

It is possible that microbial protein synthesis can by reduced at higher levels of CSFA and when the relationship between protein and the energy available to rumen fermentation are not balanced. Souza et al. (2014) reported a decrease in the levels of milk protein in Saanen goats with the addition of CSFA $(0 \%, 2.87 \%, 5.46 \%$ or $8.05 \%$ of the diet $)$ and attributed this effect to a reduction in microbial protein synthesis because, according to Santos and Pedroso (2011), microbial protein is the main source of metabolizable protein in ruminants, with a balanced amino acid profile in relation to milk protein. 


\section{Conclusions}

The addition of CSFA to goat concentrate did not influence dry matter and nutrient intake; however, CSFA influenced the rumen fermentation of goats grazing on Stargrass. Further research is suggested with the addition of CSFA to goat diets, because there is evidence that supplying CSFA increases ruminal $\mathrm{pH}$ and decreases excess ruminal ammonia without changing the volatile fatty acid concentration in the rumen fluid after grazing goats are fed with the experimental diet.

\section{Acknowledgements}

This work was supported by the Brazilian National Council of Technological and Scientific Development (Edital MCT/CNPq 14/2010 CNPq, project $\left.n^{\circ} 475673 / 2010-7\right)$.

\section{Ethical standards}

The manuscript does not contain clinical studies or patient data.

\section{Conflict of interest}

The authors declare that they have no conflict of interest.

\section{References}

ARCURI, P. B.; LOPES, F. C. F.; CARNEIRO, J. C. C. Microbiologia do rúmen. In: BERCHIELLI, T. T.; PIRES, A. V.; OLIVEIRA, S. G. (Ed.). Nutrição de ruminantes. 2. ed. Jaboticabal: FUNEP, 2011. p. 115-160.

CENKVÁRI, É.; FEKETE, S.; FÉBEL, H.; VERESEGYHÁZI, T.; ANDRÁSOFSZKY, E. Investigations on the effects of Ca-soap of linseed oil on rumen fermentation in sheep and on milk composition of goats. Journal of Animal Physiology and Animal Nutrition, Malden, v. 89, n. 3-6, p. 172-178, 2005.

DOREAU, M.; FERLAY, A. Effect of dietary lipids on nitrogen metabolism in the rumen: a review. Livestock Production Science, Amsterdam, v. 43, n. 2, p. 97-110, 1995.
GRUMMER, R. R. Influence of prilled fat and calcium salt of palm oil fatty acids on ruminal fermentation and nutrient digestibility 1. Journal of Dairy Science, Champaign, v. 71, n. 1, p. 117-123, 1988.

JENKINS, T. C.; PALMQUIST, D. L. Effect of added fat and calcium on in vitro formation of insoluble fatty acid soaps and cell wall digestibility. Journal of Animal Science, Champaign, v. 55, n. 4, p. 957-963, 1982.

LANA, R. P.; CAMARDELLI, M. M. L.; QUEIROZ, A. C.; RODRIGUES, M. T.; EIFERT, E. C.; MIRANDA, E. N.; ALMEIDA, I. C. C. Soybean oil and propolis in the diets of dairy goats. Revista Brasileira de Zootecnia, Viçosa, MG, v. 34, n. 2, p. 650-658, 2005.

LANA, R. P.; CAMARDELLI, M. M. L.; RODRIGUES, M. T.; EIFERT, E. C.; OLIVEIRA, M. V. M.; STRADIOTTI JÚNIOR, D.; OLIVEIRA, J. S. Soybean oil and propolis in the diets of dairy goats: intake of nutrients and ruminal metabolism. Revista Brasileira de Zootecnia, Viçosa, MG, v. 36, n. 1, p. 191-197, 2007.

LI, F.; YANG, X.; CAO, Y.; LI, S.; YAO, J.; LI, Z.; SUN, F. Effects of dietary effective fiber to rumen degradable starch ratios on the risk of sub-acute ruminal acidosis and rumen content fatty acids composition in dairy goat. Animal Feed Science and Technology, Amsterdam, v. 189, n. 2, p. 54-62, 2014.

MANCILLA-LEYTÓN, J.; VICENTE, A. M.; DELGADO-PERTÍÑEZ, M. Summer diet selection of dairy goats grazing in a Mediterranean shrubland and the quality of secreted fat. Small Ruminant Research, Amsterdam, v. 113, n. 2, p. 437-445, 2013.

MAYES, R. W.; LAMB, C. S.; COLGROVE, P. M. The use of dosed and herbage n-alkanes as markers for the determination of herbage intake. Journal of Agricultural Science, Cambridge, v. 107, n. 1, p. 161-170, 1986.

MEHREZ, A.; ØRSKOV, E.; MCDONALD, I. Rates of rumen fermentation in relation to ammonia concentration. British Journal of Nutrition, London, v. 38, n. 3, p. 437443, 1977.

MOLINA, B. S. L. Efeitos da inclusão de gordura protegida nas rações de cabras Saanen em lactação. 2013. Dissertação (Mestrado em Zootecnia) - Universidade Estadual de Maringá, Maringá.

NATIONAL RESEARCH COUNCIL - NRC. Nutrient requirements of small ruminants: sheep, goats, cervids, and new world camelids. Washington: National Academies Press, 2007.

ASSOCIATION OF OFFICIAL ANALYTICAL CHEMISTS - AOAC. Official methods of analysis. 15 ${ }^{\text {th }}$. Gaithersburg: Association of Official Analytical Chemists, 1990. 
. Official methods of analysis. $16^{\text {th }}$. Gaithersburg: Association of Official Analytical Chemists, 1998.

PALMQUIST, D. L. The role of dietary fats in efficiency of ruminants. Journal of Nutrition, Bethesda, v. 124, n. 8, p. 1377S-1382S, 1994. Supplement.

PALMQUIST, D. L.; CONRAD, H. Origin of plasma fatty acids in lactating cows fed high grain or high fat diets. Journal of Dairy Science, Champaign, v. 54, n. 7, p. 1025-1033, 1971.

PALMQUIST, D. L.; MATTOS, W. R. S. Metabolismo de lipídeos. In: BERCHIELLI, T. T.; PIRES, A. V.; OLIVEIRA, S. G. (Ed.). Nutrição de ruminantes. 2. ed. Jaboticabal: FUNEP, 2011. cap. 10, p. 299-322.

PRESTON, T. J. Biological and chemical analytical methods. In: PRESTON, T. J. (Ed.). Tropical animal feeding: a manual for research workers. Rome: FAO, 1995. p. 191-264.

RAPETTI, L.; BAVA, L. Feeding management of dairy goats in intensive systems. In: CANNAS, A., PULINA, G. (Ed.). Dairy goats feeding and nutrition. Cambridge: CAB International, 2008. v. 2, p. 221-237.

RUFINO, M. O. A.; ALVES, A. A.; RODRIGUES, M. M.; MOURA, R. L.; CAVALCANTE, A. C. R.; ROGÉRIO, M. C. P. Goat milk production and quality on Tanzania-grass pastures, with supplementation. Acta Scientiarum. Animal Sciences, Maringá, v. 34, n. 4, p. 417-423, 2012.

SANTOS, F. A. P.; PEDROSO, A. M. Metabolismo das proteínas. In: BERCHIELLI, T. T.; PIRES, A. V.; OLIVEIRA, S. G. (Ed.). Nutrição de ruminantes. 2. ed. Jaboticabal: Funep, 2011. p. 265-297.

SANZ SAMPELAYO, M. R.; PÉREZ, L.; MARTÍN ALONSO, J. J.; GIL EXTREMERA, F.; BOZA, J. Effects of concentrates with different contents of protected fat rich in PUFAs on the performance of lactating Granadina goats: Part I. Feed intake, nutrient digestibility, N and energy utilisation for milk production. Small Ruminant Research, Amsterdam, v. 43, n. 2, p. 133-139, 2002.

SHIBATA, H.; HASHIZUME, N.; GAZI, M. R.; SERA, K.; KATO, E.; OHMORI, T.; KANBE, M.; OBARA, Y.; KANDA, S.; KUROKAWA, Y.; ITABASHI, H. Effect of supplementation of soy sauce oil and $\mathrm{Ca}$ salts of fatty acids on rumen fermentation, milk production and conjugated linoleic acid in milk of dairy cows. Animal Science Journal, New York, v. 82, n. 4, p. 554-559, 2011.

SILVA, M. M. C.; RODRIGUES, M. T.; RODRIGUES, C.A. F.; BRANCO, R. H.; LEÃO, M. I.; MAGALHÃES, A. C. M.; MATOS, R. S. Effect of lipid supplementation on digestibility and ruminal metabolism in dairy goats. Revista Brasileira de Zootecnia, Viçosa, MG, v. 36, n. 1, p. 246-256, 2007.

SIROHI, S. K.; WALLI, T. K.; MOHANTA, R. K. Supplementation effect of bypass fat on production performance of lactating crossbred cows. Indian Journal of Animal Sciences, Champaign, v. 80, n. 8, p. 733-736, 2010.

SNIFFEN, C. J.; O'CONNOR, J. D.; VAN SOEST, P. J.; FOX, D. G.; RUSSELL, J. B. A net carbohydrate and protein system for evaluating cattle diets: II. Carbohydrate and protein availability. Journal of Animal Science, Champaign, v. 70, n. 11, p. 3562-3577, 1992.

SOUZA, R.; ALCALDE, C. R.; HYGINO, B.; MOLINA, B. S. L.; SANTOS, G. T.; GOMES, L. C. Effects of dietary energy levels using calcium salts of fatty acids on nutritive value of diets and milk quality in peripartum dairy goats. Ciência e Agrotecnologia, Lavras, v. 38, n. 3, p. 286-294, 2014.

VAN SOEST, P. J. Nutritional ecology of the ruminant. Ithaca: Cornell University Press, 1994. 476 p.

VAN SOEST, P. J.; ROBERTSON, J. B.; LEWIS, B. A. Methods for dietary fiber, neutral detergent fiber, and nonstarch polysaccharides in relation to animal nutrition. Journal of Dairy Science, Champaign, v. 74, n. 10, p. 3583-3597, 1991.

VULICH, S. A.; HANRAHAN, J. P.; CROWLEY, B. A. Modification of the analytical procedures for the determination of herbage and fecal n-alkanes used in the estimation of herbage intake. Journal of Agricultural Science, Cambridge, v. 124, n. 1, p. 71-77, 1995.

YANG, S. L.; BU, D. P.; WANG, J. Q.; HU, Z. Y.; LI, D.; WEI, H. Y.; ZHOU, L. Y.; LOOR, J. J. Soybean oil and linseed oil supplementation affect profiles of ruminal microorganisms in dairy cows. Animal, Cambridge, v. 3, n. 11, p. $1562-1569,2009$. 